Situs Jurnal : http://ejurnal.stiepancasetia.ac.id/index.php/jieb

Jilid 4 Nomor 2 Juli 2018

Hal $227-246$

\title{
PENGARUH PROFESIONALISME KERJA, PENGHARGAAN DAN PENGAWASAN KERJA TERHADAP KINERJA TENAGA KONTRAK KEBERSIHAN BIDANG PERTAMANAN DAN KEBERSIHAN DI DINAS PEKERJAAN UMUM, PENATAAN RUANG, PERUMAHAN DAN KAWASAN PERMUKIMAN KABUPATEN KAPUAS
}

\section{Rini Mardianie*}

Abstract: Objectives to be achieved in this research is To know and analyze the influence of work professionalism, awards and supervision of work to the performance of contract work contracts of Gardening and Cleanliness Hygiene in Public Works Department, Spatial Planning, Housing and Settlement Area of Kapuas Regency, simultaneously and partially, also to understand which variable has the dominant effect.Data processing techniques to be performed by the author is to use quantitative methods. Analysis of research data using multiple regression analysis through computer spss while the sample in this study were as many as 66 respondents. The result of the research showed that the variables of work professionalism, reward variable and work supervision variable simultaneously and partially have a significant effect on the performance variable of contract workforce of Gardening and Cleanliness Hygiene in Public Works Department, Spatial Planning, Housing and Settlement Area of Kapuas Regency. Among those variables, work professionalism have a dominant influence on the performance of contract workers in the Cleaning and Gardening Sector in Public Works, Spatial Planning, Housing and Settlement Area of Kapuas Regency.

Keywords: Work Professionalism, Awards, Work Supervision and Performance

Abstrak: Tujuan yang ingin dicapai dalam penelitian ini adalah Untuk mengetahui dan menganalisis pengaruh profesionalisme kerja, penghargaan dan pengawasan kerja terhadap kinerja tenaga kerja kontrak Kebersihan Bidang Pertamanan dan Kebersihan di Dinas Pekerjaan Umum, Penataan Ruang, Perumahan dan Kawasan Permukiman Kabupaten Kapuas, baik secara simultan maupun parsial, serta mengetahui variabel mana yang dominan. Teknik pengolahan data yang akan dilakukan oleh penulis adalah dengan menggunakan metode kuantitatif. Analisis data penelitian menggunakan analisis regresi berganda melalui komputer spss sedangkan sampel dalam penelitian ini adalah sebanyak 66 responden. Hasil penelitian menunjukkan bahwa variabel profesionalisme kerja, variabel penghargaan dan variabel pengawasan kerja secara simultan maupun parsial berpengaruh signifikan terhadap variabel kinerja tenaga kerja kontrak Kebersihan Bidang Pertamanan dan Kebersihan di Dinas Pekerjaan Umum, Penataan Ruang, Perumahan dan Kawasan Permukiman Kabupaten Kapuas. Dari ketiga variabel tersebut, variabel profesionalisme kerja berpengaruh dominan terhadap kinerja tenaga kerja kontrak Kebersihan Bidang Pertamanan dan Kebersihan di Dinas Pekerjaan Umum, Penataan Ruang, Perumahan dan Kawasan Permukiman Kabupaten Kapuas.

Kata kunci : Profesionalisme Kerja, Penghargaan, Pengawasan Kerja dan Kinerja ......

* Dinas Pekerjaan Umum, Penataan Ruang, Perumahan Dan Kawasan Permukiman 


\section{Latar Belakang}

Dinas Pekerjaan Umum, Penataan Ruang, Perumahan dan Kawasan Permukiman Kabupaten Kapuas merupakan sebuah instansi pemerintah yang bertugas menyelenggarakan urusan bidang pekerjaan umum, selama ini mengharapkan para pegawainya khususnya pegawai/tenaga kontrak selalu dapat bekerja dengan baik sesuai dengan fungsi dan tugasnnya, namun hal tersebut tidak berjalan sesuai dengan harapan, yang mana selama ini pegawai yang berstatus tenaga kontrak kadang dalam bekerja kurang maksimal karena dalam bekerja hanya mampu dalam satu bidang pekerjaan dan tidak menguasai bidang lain apabila mendapatkan pemindahan tugas dalam bidang pekerjaannya. Selain itu para pegawai ini dalam bekerja kerap kali selalu menunggu perintah dalam bekerja atau tidak mempunyai inisiatif sendiri dalam bekerja terkesan pegawai tersebut kurang profesional dalam bekerja. Selain itu selama ini juga semangat kerja pegawai kontrak tersebut terlihat kurang optimal, berdasarkan hasil wawancara awal penulis diketahui bahwa mereka merasa bekerja selama ini kurang dihargai oleh pihak manajemen Dinas Pekerjaan Umum, Penataan Ruang, Perumahan dan Kawasan Permukiman Kabupaten Kapuas.

Hasil kerja pegawai kontrak tersebut kerap kali tidak mendapatkan penghargaan yang sesuai dengan harapan pegawai, sehingga menyebabkan semangat dan kinerja pegawai menjadi kurang optimal. Melihat aktivitas tersebut dapat dikatakan bahwa peran pengawasan terhadap aktivitas kerja pegawai kontrak masih belum maksimal dilaksanakan oleh pihak Dinas Pekerjaan Umum, Penataan Ruang, Perumahan dan Kawasan Permukiman Kabupaten Kapuas, sehingga fungsinya diharapkan mempu menciptakan efisiensi dan efektifitas kerja yang dilakukan oleh para pegawai. Dengan pengawasan yang baik diharapkan akan berkurangnya kesalahan dan penyimpangan yang terjadi. Tugas seorang pemimpin adalah untuk mengawasi para pegawai yang ada dalam lingkup organisasinya. Berdasarkan dengan permasalahan tersebut, maka penulis tertarik untuk mengadakan penelitian dengan materi judul Pengaruh Profesionalisme Kerja, Penghargaan dan Pengawasan Kerja Terhadap Kinerja Tenaga Kontrak Kebersihan Bidang Pertamanan dan Kebersihan di Dinas Pekerjaan Umum, Penataan Ruang, Perumahan dan Kawasan Permukiman Kabupaten Kapuas.

Berdasarkan latar belakang yang telah penulis kemukakan tersebut, maka yang menjadi perumusan masalah dalam peneltian ini adalah sebagai berikut:

1. Apakah profesionalisme kerja, penghargaan dan pengawasan kerja secara simultan berpengaruh signifikan terhadap kinerja tenaga kerja kontrak Kebersihan Bidang Pertamanan dan Kebersihan di Dinas Pekerjaan Umum, Penataan Ruang, Perumahan dan Kawasan Permukiman Kabupaten Kapuas?

2. Apakah profesionalisme kerja, penghargaan dan pengawasan kerja secara parsial berpengaruh signifikan terhadap kinerja tenaga kerja kontrak Kebersihan Bidang Pertamanan dan Kebersihan di Dinas Pekerjaan Umum, Penataan Ruang, Perumahan dan Kawasan Permukiman Kabupaten Kapuas?

3. Diantara variabel profesionalisme kerja, penghargaan dan pengawasan kerja manakah yang berpengaruh dominan terhadap kinerja tenaga kerja kontrak Kebersihan Bidang Pertamanan dan Kebersihan di Dinas Pekerjaan Umum, Penataan Ruang, Perumahan dan Kawasan Permukiman Kabupaten Kapuas?

\section{Kajian Literatur}

Menurut Suseno (2007:97) profesional adalah pekerja yang menjalankan profesi. Setiap profesional berpegang pada nilai moral yang mengarahkan dan mendasari perbuatan luhur. Dalam melakukan tugas profesi, para profesional harus bertindak objektif, artinya bebas dari rasa malu, sentimen, benci, sikap malas dan enggan bertindak. Dengan demikian seorang profesional jelas harus memiliki profesi tertentu yang diperoleh melalui sebuah proses pendidikan maupun pelatihan yang khusus, dan disamping itu pula ada unsur semangat 
pengabdian (panggilan profesi) didalam melaksanakan suatu kegiatan kerja. Hal ini perlu ditekankan benar untuk membedakannya dengan kerja biasa (occupation) yang semata bertujuan untuk mencari nafkah dan/ atau kekayaan materiil duniawi. Menurut Korten dan Alfonso, dalam (Tjokrowinoto, 2006: 178), bahwa profesionalisme adalah kecocokan (fitness) antara kemampuan yang dimiliki oleh birokrasi (bureaucratic-competence) dengan kebutuhan tugas (task-requirement). Pegawai yang memiliki kemampuan yang sejalan dengan kebutuhan tugas yang dilakukannya dalam bekerja merupakan syarat terciptanya pegawai yang profesional. Maksudnya kemampuan dan keahlian pegawai merupakan suatu pencerminan dari arah dan tujuan yang ingin dicapai sebuah organisasi. Dengan demikian, apabila bagian organisasi ingin melayani masyarakat banyak untuk terciptanya good governance, maka Bagian Organisasi haruslah memiliki aparat yang profesionalisme demi tercapainya tujuan organisasi.

Selanjutnya pendapat Siagian (2007:163), mengatakan, bahwa profesionalisme merupakan keandalan dalam pelaksanaan tugas sehingga terlaksana dengan mutu tinggi, waktu yang tepat, cermat dan dengan prosedur yang mudah dipahami dan diikuti oleh pelanggan. Pegawai yang profesional akan handal dalam bertugas yang pada akhirnya akan menghasilkan kerja yang bermutu tinggi, waktu yang tepat prosedur yang bisa diikuti masyarakat yang dilayaninya. Supaya handal tentunya dibutuhkan pendidikan dan latihan yang akan mendukung pegawai dalam bekerja agar dapat merespon kebutuhan dan perkembangan lingkungan yang semakin pesat pada era otonomi sekarang agar bisa melayani kepentingan masyarakat secara efektif dan memiliki daya inovatif yang tinggi mengacu pada visi dan misi Organisasi. Untuk mengukur profesionalisme pegawai dalam pelaksanaan tugasnya bukanlah suatu hal yang mudah dalam rangka mencapai tujuan organisasi seiring dengan misi yang diemban.

Ada berbagai pendapat untuk mengukur profesionalisme. Menurut Ancok (2008:104), pengukuran profesionalisme adalah:

1. Kemampuan beradaptasi

2. Kemampuan dalam menyesuaikan diri dengan fenomena global dan fenomena nasional mengacu kepada misi dan nilai (mission\&values driven professionalisme), birokrasi memposisikan diri sebagai pemberi pelayanan kepada publik dan dalam mewujudkan tujuan organisasi yang berorientasi pada hasil yang ingin dicapai organisasi.

Kemudian menurut Suradinata (2005:101) adapun sikap seorang yang professional, yaitu:

1. Komitmen tinggi

2. Tanggung jawab

3. Berfikir sistematis

4. Penguasaan materi

5. Menjadi bagian masyarakat professional

Profesionalesme harus didukung oleh faktor-faktor lain sebagai penunjangnya. Faktor yang mendukung sikap profesionalisme menurut Royen (2007:13) adalah :

a. Performance

Performance dapat diartikan sebagai prestasi kerja, pelaksanaan kerja, penampilan kerja. Performance atau kehandalan serta prestasi kerja adalah hasil yang diinginkan dari prelaku, prestasi yang dihasilkan dalam urutan maupun kurun waktu tertentu. Prestasi kerja dapat dilihat dari kuantitas kerja, kualitas kerja, pengetahuan tentang pekerjaan dan pendapat atau pernyataan yang disampaikan. 
b. Akuntabilitas Aparatur

Akuntabilitas merupakan kebijakan strategis, hal ini harus dapat di implementasikan untuk menciptakan kepatuhan pelaksanaan tugas dan kinerja pegawai. Akuntabilitas juga merupakan kewajiban untuk memberikan tanggung jawab kinerja kepada pihak-pihak tertentu.

c. Loyalitas Pegawai

Loyalitas aparatur yang berkaitan dengan karakteristik sosok profesionalisme menurut Islami dalam Royen adalah kesetiaan diberikan kepada konstitusi, hukum, pimpinan, bawahan dan rekan sekerja, berbagai jenis kesetiaan tersebut terkait satu sama lain dan tidak ada kesetiaan yang mutlak diberikan kepada satu jenis kesetiaan tertentu dengan mengabaikan yang lainnya.

\section{d. Kemampuan Aparatur / Pegawai}

Merupakan salah satu unsur kematangan yang berkaitan dengan pengetahuan dan keterampilan yang diperoleh dari pendidikan dan pelatihan serta pengalaman. Profesionalisme pegawai sangat ditentukan oleh tingkat kemampuan pegawai yang tercermin dalam perilaku sehari- hari. Istilah tersebut mengacu kepada potensi pegawai dalam mengerjakan tugas dan bagiannya.

Suradinata (2005:121) menjelaskan cara pengembangan profesionalisme kerja diperlukan proses pendidikan, pelatihan dan pembelajaran bagi para pegawai. Berdasarkan kategori pegawai, pelatihan dapat berupa program orientasi pegawai baru, pelatihan umum secara ekstensif, pelatihan job spesifik, praktik standar secara bertahap, pelatihan peralatan dan prosedur operasi dan adapun cara pengembangan profesionalisme kerja dapat dilaksanakan dengan kegiatan-kegiatan berikut ini :

1. Menyelenggarakan kegiatan penataran dan pelatihan terhadap para pekerja yang dilaksanakan secara bertahap dan berkesinambungan.

2. Memberikan kesempatan kepada para pekerja untuk melanjutkan pendidikan ke tingkat lebih tinggi.

3. Mengirim atau menyekolahkan para pekerja pilihan keluar negeri.

4. Menyelenggarakan kegiatan seminar, loka karya atau workshop yang berkaitan dengan peningkatan kualitas tenaga kerja.

5. Menyediakan fasilitas dan bantuan dana kepada para pekerja yang berprestasi untuk meningkatkan keahlian di bidangnya.

Sistem reward (penghargaan) penting bagi organisasi/ instansi karena mencerminkan upaya organisasi untuk mempertahankan SDM sebagai komponen utama dan merupakan biaya yang penting, disamping pertimbangan tersebut penghargaan juga merupakan salah satu aspek yang berarti bagi pegawai, karena individu atau pegawai besarnya penghargaan mencerminkan bentuk perhatian dari instansi terhadap prestasi yang dihasilkan pegawai. Pemberian penghargaan bisa berbentuk materi maupun non materi, bentuk materi bisa berbentuk bonus, insentif maupun tanda penghargaan, sedangkan non materi bisa berbentuk ucapan pujian maupun penghargaan dalam bentuk mendali. (Danim, 2009:126) Reward (penghargaan) kegiatan dimana organisasi menilai konstribusi pegawai dalam rangka mendistribusikan penghargaan moneter dan non moneter cukup langsung dan tidak langsung dalam kemampuan organisasi untuk membayar berdasarkan peraturan hukum (Schuler (1997:102).

Hasibuan (2007:135) menjelaskan reward (penghargaan) adalah semua pendapatan yang berbentuk uang, barang langsung atau tidak langsung yang diterima pegawai sebagai 
imbalan atau jasa yang diberikan kepada perusahaan/organisasi. Nitisemito (1996:87) menjelaskan reward (penghargaan) merupakan balas jasa yang diberikan oleh perusahaan/organisasi kepada para pegawai yang dapat dinilai dengan uang dan mempunyai kecenderungan diberikan secara tetap. Penghargaan berarti semua bentuk penggajian atau ganjaran kepada pegawai dan timbul karena pegawai mereka dapat bekerja secara baik.

Penghargaan tersebut bisa berbentuk uang secara langsung (uang, gaji, insentif, bonus) dan dapat pula berbentuk pembayaran tidak langsung (asuransi dan liburan). Pemberian reward (penghargaan) mempunyai tujuan sebagai ikatan kerjasama, kepuasan kerja, pengadaan efektif, stabilitas pegawai dan disiplin (Hasibuan 2007:119) dijabarkan sebagai berikut:

1. Ikatan kerjasama, tujuannya untuk membantu meningkatkan ikatan kerjasama antar pegawai dalam bekerja.

2. Kepuasan kerja, tujuannya untuk meningkatkan kepuasan pegawai dalam bekerja.

3. Pengadaan efektif untuk meningkatkan kondisi pegawai agar dapat bekerja dan betah dalam bekerja.

4. Motivasi, tujuannya untuk meningkatkan motivasi pegawai dalam bekerja.

5. Stabilitas pegawai disiplin,tujuannya untuk membantu meningkatkan disiplin pegawai dalam bekerja.

Menurut Swansburg, (1999:349) pemberian reward (penghargaan) dapat memberikan dampak positif terhadap perilaku pegawai, menimbulkan kepuasan kerja bagi pegawai, memberikan dampak positif terhadap kemampuan organisasi, mampu menghasilkanlah dirancang dan pancapaian tujuan yang tujuan yang telah dirancang dan mempertahankan lebih banyak pegawai yang mampu dalam bekerja untuk mencapai prestasi yang tinggi. Sedangkan Hasibuan (2007:99) menjelaskan alat-alat untuk memberikan penghargaan kerja adalah :

1. Pemberian dalam bentuk materiil insentif, yaitu alat motivasi yang diberikan dapat berupa uang dan atau barang yang mempunyai nilai pasar, yang dapat memberikan kebutuhan ekonomis, seperti : Kendaraan, rumah, dan lain-lain.

2. Non materiil insentif, yaitu alat penghargaan yang diberikan berupa barang /benda yang tidak ternilai, yaitu hanya memberikan kepuasan/kebanggaan rohani saja, seperti medali, piagam, bintang jasa, dan lain-lain

3. Kombinasi materiil dan nonmateriil insentif, yaitu alat motivasi yang diberikan untuk berupa materiil (uang dan barang) dan non materiil (medali dan piagam) yaitu pemenuhan ekonomis dan kepuasan.

Sistem penghargaan ini sangat penting dalam menunjang aktivitas kerja, karena dengan adanya perhatian berupa penghargaan, maka motivasi seseorang dalam bekerja akan tumbuh. Menurut Sardiman (2002:89), macam-macam reward adalah sebagai berikut:

1. Pemberian hadiah

Hadiah dapat juga dikatakan sebagai motivasi berprestasi. Sebagian pegawai merasa senang dan bangga apabila dia diberikan hadiah atas prestasinya yang baik atau penilai kerja yang baik di kantor oleh pimpinan.

2. Pemberian pujian

Pemberian pujian disini adalah bentuk reinforcement yang positif dan sekaligus merupakan motivsi berprestasi maka pemberiannya harus tepat. Dengan pujian yang tepat akan memupuk suasana yang menyenangkan dan mempertinggi gairah kerja serta sekaligus akan membangkitkan harga diri pegawai sehingga prestasi kerja ikut meningkat. 
3. Pemberian penghargaan

Semua hal yang dilakukan oleh siswa harus dihargai agar pegawai tidak merasa perbuatannya sia-sia. Penghargaan yang bisa diberikan kepada pegawai dapat berupa piagam, piala atau sertifikat.

Penghargaan (reward) dalam berprestasi merupakan dorongan untuk memotivasi pegawai dalam bekerja. Dorongan intelektual adalah keinginan untuk mencapai suatu prestasi yang hebat. (http:// pakdesefa. blog2.plasa.com). Menurut Soemanto (1998:123) bahwa tingkah laku manusia itu dikendalikan oleh ganjaran (reward) atau penguatan (reinforcement) dari lingkungan. Sedangkan menurut Skinner dalam teori Skinner's Operant Conditioning menganggap bahwa reward atau reinforcement sebagai faktor terpenting dalam proses kerja untuk mencapai prestasi kerja yang bagus.

Soerwarno (1998:143) mengemukakan pengawasan merupakan suatu proses dimana pimpinan mengetahui apakah hasil pelaksanaan pekerjaan yang dilakukan oleh bawahannya sesuai dengan rencana, pemerintah, tujuan dan kebijaksanaan yang telah ditetapkan. Siagian (2001:135) menjelaskan "pengawasan adalah proses pengamatan dari pada seluruh pelaksanaan kegiatan organisasi untuk menjadi agar supaya semua pekerjaan yang sedang dilakukan berjalan sesuai rencana yang telah ditentukan sebelumnya". Abdurrachman (2008:69) mengemukakan akan pengertian dari pengawasan adalah suatu kegiatan atau proses kegiatan untuk mengetahui hasil pelaksanaan, kesalahan, kegagalan untuk memperbaiki dan kemudian terulangnya kembali kelemahan-kelemahan itu begitu pula mencegah kegagalan sehingga pelaksanaan tidak berbeda dengan rencana yang ditetapkan. Menurut Sosrohamidjojo (2002:12) mengemukakan akan pengertian dari pengawasan, yaitu salah satu fungsi terpenting dalam manajemen adalah fungsi pengawasan yang secara umum dapat dirumuskan dalam hal menilai pelaksanaan tugas pekerjaan adalah sesuai deng rencana yang ditetapkan serta hasil yang dikehendaki dan bilamana perlu mengambil tindakantindakan kolektif.

Handoko (2004:77) menjelaskan "pengawasan merupakan suatu proses dimana pimpinan mengetahui akan hasil pelaksanaan pekerjaan yang dilakukan oeh bawahannya sesuai dalam rencana, perintah, tujuan dan kebijaksanaan yang telah ditetapkan. Sedangkan menurut Sujatmo (2000:12) "pengawasan adalah puncak pengamatan dari pada pelaksanaan seluruh kegiatan organisasi untuk menjamin agar supaya pekerjaan yang sedang dilakanakan berjalan sesuai dengan rencana yang telah ditentukan sebelumnya". Dari definisi tersebut dapat ditarik kesimpulan bahwa pengawasan adalah kegiatan yang dilakukan oleh pimpinan agar setiap pekerjaan yang berkaitan dengan organisasi dapat dilaksanakan sesuai dengan yang telah direncanakan serta mencapai hasil guna dan daya guna.

Pengawasan memiliki bentuk yang berbeda-beda. Menurut Handayaningrat (2006:144) terdapat empat jenis pengawasan, yaitu:

1. Pengawasan dari dalam (internal control)

Pengawasan dari dalam berarti pengawasan yang dilakukan oleh aparat atau petugas pengawas yang dibentuk dalam organisasi itu sendiri.

\section{Pengawasan dari luar (external control)}

Pengawasan yang dari luar berartii pengawasan yang dilakukan oleh aparat pengawas diluar organisasi itu atau bertindak atas nama pimpinan organisasi karena diminta.

\section{Pengawasan preventif}

Pengawasan preventif adalah pengawasan yang dilakukan sebelum rencana dilaksanakan. 
4. Pengawasan represif

Pengawasan represif adalah pengawasan yang dilakukan setelah pelaksanaan pekerjaan.

Manullang (2008:2) mengemukakan empat macam pengawasan yang berbeda lagi, yaitu sebagai berikut:

1. Pengawasan dengan ukuran atau disebut tolak ukur

2. Pengawasan dengan membandingkan kegiatan serta monitoring

3. Pengawasan dengan membandingkan proses kegiatan dengan ukuran yang ditetapkan.

4. Pengawasan dengan langsung mengadakan tindakan korektif

Menurut G. R. Terry dalam Sukama (1992, hal. 116) proses pengawasan terbagi atas 4 tahapan, yaitu:

1. Menentukan standar atau dasar bagi pengawasan.

2. Mengukur pelaksanaan

3. Membandingkan pelaksanaan dengan standar dan temukanlah perbedaan jika ada.

4. Memperbaiki penyimpangan dengan cara-cara tindakan yang tepat.

Dari pendapat diatas dapat disimpulkan bahwa proses pengawasan dilakukan berdasarkan beberapa tahapan yang harus dilakukan.

1. Menetapkan standar pelaksanaan (perencanaan)

Sehingga dalam melakukan pengawasan manajer mempunyai standard yang jelas.

2. Penentuan pengukuran pelaksanaan kegiatan

Mengukur kinerja pegawai, sejauh mana pegawai dapat menerapkan perencanaan yang telah dibuat atau ditetapkan perusahaan sehingga perusahaan dapat mencapai tujuannya secara optimal.

3. Pembandingan pelaksanaan kegiatan dengan standard dan penganalisa penyimpanganpenyimpangan

4. Pengambilan tindakan koreksi

Melakukan perbaikan jika ditemukan penyimpangan-penyimpangan yang terjadi.

Kinerja adalah hasil kerja secara kualitas dan kuantitas yang dicapai oleh seorang pegawai dalam melaksanakan tugasnya sesuai dengan tanggung jawab yang diberikan kepadanya. Tinggi rendahnya kinerja pekerja berkaitan erat dengan sistem pemberian penghargaan yang diterapkan oleh lembaga/organisasi tempat mereka bekerja. Kinerja juga dapat diartikan sebagai suatu hasil dan usaha seseorang yang di capai dengan adanya kemampuan dan perbuatan dalam situasi tertentu. Menurut Mangkunegara, (2001: 67) "kinerja adalah hasil kerja secara kualitas dan kuantitas yang dicapai oleh seorang pegawai dalam melaksanakan tugasnya sesuai dengan tanggung jawab yang di berikan kepadanya.

Menurut Handoko (2010;45) kinerja adalah catatan tentang hasil-hasil yang diperoleh dari fungsi-fungsi pekerjaan atau kegiatan tertentu selama kurun waktu tertentu. Menurut As'ad (2001:90) kinerja adalah keberhasilan seseorang dalam melakukan suatu pekerjaan. Kinerja pegawai adalah sebuah evaluasi dari kontribusi karyawan terhadap pencapaian tujuan organisasi dalam, Baldauf,dkk., 2001,p.219). Secara konseptual berguna untuk menguji kinerja pegawai dalam hal:

1. Perilaku atau aktifitas yang dilakukan oleh karyawan

2. Outcome yang bisa diatribusikan bagi usaha-usaha.

Marihot (2012) berpendapat bahwa kinerja merupakan hasil kerja yang dihasilkan oleh pegawai atau perilaku nyata yang ditampilkan sesuai peranannya dalam organisasi. Kinerja juga berarti hasil yang dicapai seseorang baik kualitas maupun kuantitas sesuai dengan 
tanggungjawab yang diberi kepadanya. Selain itu kinerja seseorang dipengaruhi oleh tingkat pendidikan, inisiatif, pengalaman kerja, dan motivasi karyawan. Hasil kerja seseorang akan memberikan umpan balik bagi orang itu sendiri untuk selalu aktif melakukan pekerjaannya secara baik dan diharapkan akan menghasilkan mutu pekerjaan yang baik pula. Pendidikan mempengaruhi kinerja seseorang karena dapat memberikan wawasan yang lebih luas untuk berinisiatif dan berinovasi dan selanjutnya berpengaruh terhadap kinerjanya.

Terdapat beberapa indikator untuk mengukur kinerja. Indikator kinerja karyawan menurut Guritno dan Waridin (2005:123) adalah:

1. Mampu meningkatkan target pekerjaan

2. Mampu menyelesaikan pekerjaan tepat waktu

3. Mampu menciptakan inovasi dalam menyelesaikan pekerjaan

4. Mampu menciptakan kreativitas dalam menyelesaikan pekerjaan

5. Mampu meminimalkan kesalahan pekerjaan

Menurut Prawirisentono (1999:27) dapat dijelaskan pula beberapa faktor-faktor lain yang mempengaruhi kinerja adalah:

1. Efektivitas dan efensiensi.

Bila suatu tujuan tertentu akhirnya bisa dicapai, kita boleh mengatakan bahwa kegiatan tersebut efektif tetapi apabila akibat-akibat yang tidak dicari kegiatan mempunyai nilai yang penting dari hasil yang dicapai sehingga mengakibatkan ketidakpuasan walaupun efektif dinamakan tidak efisien. Sebaliknya bila akibat yang dicari-cari tidak penting maka kegiatan tersebut efektif.

2. Otoritas (wewenang).

Arti otoritas adalah sifat dari suatu komunikasi atau perintah dalam suatu organisasi formal yang dimiliki (diterima) oleh seorang anggota organisasi kepada anggota lain untuk melakukan suatu kegiatan kerja sesuai dengan kontribusinya (sumbangan tenaganya). Perintah tersebut menyatakan apa boleh dilakukan dan tidak boleh dilakukan dalam organisasi tersebut. Ketiga,

3. Disiplin

Disiplin adalah taat kepada hukum dan peraturan yang berlaku. Jadi, disiplin karyawan adalah kegiatan karyawan yang bersangkutan dalam menghormati perjanjian kerja dengan organisasi dimana dia bekerja.

\section{Inisiatif}

Yaitu berkaitan dengan daya pikir dan kreativitas dalam bentuk ide untuk merencanakan sesuatu yang bertujuan dengan organisasi. Jadi, inisiatif adalah daya dorong kemajuan yang bertujuan untuk mempengaruhi kinerja organisasi.

Menurt Dessler (2000) terdapat lima buah faktor dalam penilaian kinerja yang populer, yaitu

1. Prestasi pekerjaan, meliputi: akurasi, ketelitian, keterampilan, dan penerimaan keluaran.

2. Kuantitas pekerjaan, meliputi: volume keluaran dan kontribusi,

3. Kepemimpinan yang diperlukan, meliputi: membutuhkan saran, arahan atau perbaikan.

4. Kedisiplinan, meliputi: kehadiran, sanksi, warkat, regulasi, dapat dipercaya/diandalkan.

5. Ketepatan waktu, komunikasi, meliputi: hubungan antar karyawan maupun dengan pimpinan, media komunikasi. 
Selain itu Rivai (2009:548) menjelaskan indikator dalam penilaian kinerja karyawan dapat dilihat dari beberapa hal berikut ini, yaitu:

1. Kualitas Output yaitu hasil yang dicapai karyawan dalam bekerja sesuai dengan apa yang ditetapkan.

2. Kuantitas Output yaitu jumlah atau beban kerja yang dihasilkan karyawan dapat dicapai sesuai dengan yang ditargetkan oleh pihak organisasi.

3. Jangka Waktu Ouput yaitu efesiensi waktu dalam melaksanakan pekerjaan dapat dicapai karyawan dalam bekerja.

4. Kehadiran ditempat Kerja yaitu tingkat keaktifan karyawan dalam bekerja yang dibebankan selama ini dapat dilaksanakan sesuai dengan aturan.

5. Sifat Kooperatif yaitu adanya sikap yang baik dan aktif dari karyawan dalam bekerja terhadap pelaksanaan tugas, tanggung jawab yang dibebankan oleh organisasi dapat dilaksanakan dengan baik.

\section{Metode Penelitian}

Teknik pengolahan data yang akan dilakukan oleh penulis adalah dengan menggunakan metode kuantitatif. Metode kuantitatif adalah metode yang lebih memanfaatkan angka-angka statistik untuk membuat suatu kesimpulan, sehinga mampu memberikan hasil analisis yang lebih akurat dibandingkan penelitian kualitatif. Analisis data penelitian ini adalah uji deskriptif untuk mengetahui karakteristik responden dan kondisi masing-masing variabel dimata responden, serta analisis regresi linear berganda yang diproses menggunakan program komputer SPSS.

Populasi pada peneliian ini adalah seluruh kinerja tenaga kerja kontrak Kebersihan Bidang Pertamanan dan Kebersihan di Dinas Pekerjaan Umum, Penataan Ruang, Perumahan dan Kawasan Permukiman Kabupaten Kapuas. Sampel diammbil sebanyak 66 responden

\section{Hasil Penelitian dan Pembahasan}

Ketepatan hipotesis sangat bergantung pada data yang dipergunakan dalam pengujian tersebut untuk itu digunakan analisis data dan pembahasan beberapa uji data, yaitu sebagai berikut:

\section{Uji Validitas}

Uji validitas dan reliabilitas dalam penelitian ini dilakukan dengan menggunakan One Shot Method sering disebut dengan pengujian internal consistency dengan metode ini pengukuran cukup dilakukan satu kali. Uji validitas dapat diketahui melihat nilai rhitung dan untuk mengetahui validitas instrument pertanyaan harus dibandingkan dengan rtabel pada $\alpha 0,05$.

Tabel 1. Uji Validitas Variabel Profesionalisme Kerja (X1)

\begin{tabular}{cccc}
\hline Variable & R hitung & R tabel & Validitas \\
\hline X1.1 & $0,478(* *)$ & 0,242 & Valid \\
X1.2 & $0,671(* *)$ & 0,242 & Valid \\
X1.3 & $0,612(* *)$ & 0,242 & Valid \\
\hline
\end{tabular}

Hasil uji validitas terhadap instrumen pertanyaan profesionalisme kerja (X1) yang diajukan dapat disimpulkan bahwa semua instrumen pertanyaan tersebut valid ini terbukti dengan membandingkan ( $\mathrm{r}$ hitung) dengan rtabel pada $\alpha 0,05$ yang mana diambil keputusan jika nilai rhitung positif dan $r$ hitung $>r$ tabel, maka instrumen pertanyaan tersebut valid. 
Tabel 2 Uji Validitas Variabel Penghargaan (X2)

\begin{tabular}{cccc}
\hline Variable & R hitung & R tabel & Validitas \\
\hline X2.1 & $0,342(* *)$ & 0,242 & Valid \\
X2.2 & $0,641(* *)$ & 0,242 & Valid \\
X2.3 & $0,371(* *)$ & 0,242 & Valid \\
X2.4 & $0,367(* *)$ & 0,242 & Valid \\
\hline
\end{tabular}

Hasil uji validitas terhadap instrumen pertanyaan penghargaan (X2) yang diajukan dapat disimpulkan bahwa semua instrumen pertanyaan tersebut valid ini terbukti dengan membandingkan (rhitung) dengan rtabel pada $\alpha 0,05$ yang mana diambil keputusan jika nilai rhitung positip dan rhitung > rtabel, maka instrumen pertanyaan tersebut valid.

Tabel 3. Uji Validitas Variabel Pengawasan Kerja (X3)

\begin{tabular}{cccc}
\hline Variable & R hitung & R tabel & Validitas \\
\hline X3.1 & $0,366(* *)$ & 0,242 & Valid \\
X3.2 & $0,499(* *)$ & 0,242 & Valid \\
X3.3 & $0,474(* *)$ & 0,242 & Valid \\
X3.4 & $0,504(* *)$ & 0,242 & Valid \\
X3.5 & $0,339(* *)$ & 0,242 & Valid \\
\hline
\end{tabular}

Hasil uji validitas terhadap instrumen pertanyaan pengawasan kerja (X3) yang diajukan dapat disimpulkan bahwa semua instrumen pertanyaan tersebut valid ini terbukti dengan membandingkan (rhitung) dengan rtabel pada $\alpha 0,05$ yang mana diambil keputusan jika nilai rhitung positip dan rhitung > rtabel, maka instrumen pertanyaan tersebut valid.

Table 4. Uji Validitas Variabel Kinerja Tenaga Kontrak (Y)

\begin{tabular}{cccc}
\hline Variable & R hitung & R tabel & Validitas \\
\hline Y1.1 & $0,377(* *)$ & 0,242 & Valid \\
Y1.2 & $0,450(* *)$ & 0,242 & Valid \\
Y1.3 & $0,595(* *)$ & 0,242 & Valid \\
Y1.4 & $0,412(* *)$ & 0,242 & Valid \\
Y1.5 & $0,388(* *)$ & 0,242 & Valid \\
\hline
\end{tabular}

Hasil uji validitas terhadap instrument kinerja tenaga kontrak (Y) yang diajukan dapat disimpulkan bahwa semua instrumen pertanyaan tersebut valid ini terbukti dengan membandingkan (rhitung) dengan rtabel pada $\alpha 0,05$ yang mana diambil keputusan jika nilai rhitung positip dan rhitung > rtabel, maka instrumen pertanyaan tersebut valid.

2. Uji Reliabilitas

Reliabilitas sebenarnya adalah alat untuk mengukur suatu kuesioner yang merupakan indikator dari variabel atau konstruk. Suatu kuesioner dikatakan reliabel atau handal jika jawaban seseorang terhadap pernyataan adalah konsisten atau stabil dari waktu ke waktu. SPSS memberikan fasilitas untuk mengukur reliabilitas dengan uji statistic Cronbach Alpha $(\alpha)$. Suatu konstruk atau variabel dikatakan reliabel jika memberikan nilai Cronbach Alpha minimum 0,5. (Santoso, 2004, 280). Suatu konstruk atau variabel dikatakan reliabel jika memberikan nilai Cronbach $\mathrm{A}_{1 \mathrm{pha}}>0,60$. (Ghozali, 2006, 41-42). Setelah dilakukan pengujian reliabilitas maka hasil dari jawaban kuesioner adalah reliabel. 
Tabel 5. Hasil Uji Reliabilitas

\begin{tabular}{lccc}
\hline \multicolumn{1}{c}{ Variable } & Cronbach A $\mathrm{A}_{\text {lpha }}$ & Nilai Baku & Keterangan \\
\hline Profesionalisme Kerja (X1 & 0,617 & 0,60 & Reliabel \\
Penghargaan (X2) & 0,689 & 0,60 & Reliabel \\
Pengawasan Kerja (X3) & 0,746 & 0,60 & Reliabel \\
Kinerja Tenaga Kontrak (Y) & 0,644 & 0,60 & Reliabel \\
\hline
\end{tabular}

3. Pengujian Asumsi Klasik

Setelah data diuji dengan uji kualitas data berupa uji validitas dan reabilitas, selanjutnya adalah pengujian atau evaluasi terhadap model analisis regresi liner berganda, sehingga menghasilkan Pemeriksaan Linear Terbaik Tak Bias (Best Linear Unbiased Estimator $(B L U E)$. Evaluasi ini dimaksudkan untuk mengetahui apakah regresi linear berganda sebagai alat analisis telah memenuhi beberapa asumsi klasik. Jenis-Jenis uji asumsi klasik yang dilakukan pada penelitian ini meliputi:

a. Uji Multikolinearitas

Uji multikolinearitas bertujuan untuk menguji apakah model regresi yang digunakan telah ditemukan adanya korelasi (hubungan) antara variabel bebas (independent) yang satu dengan variabel bebas yang lainnya. Model regresi yang baik seharusnya tidak terjadi korelasi antara variabel bebas. Regresi yang bebas multikolinearitas ditandai dengan nilai VIF berkisar angka 1 dan nilai Tolerance berkisar angka 1 (VIF = 1/tolerance) (Pratisto, 2004, 161) dan menurut Solimun $(2004,35)$ apabila beberapa nilai VIF lebih dari 5, maka multikolinearitas adalah sebuah masalah.

Tabel 6. Analisis Tolerance dan Variance Inflation Factor

\begin{tabular}{crrr}
\hline Variabel & \multicolumn{2}{c}{ Collinierarity Statistic's } & Kesimpulan \\
\cline { 2 - 3 } & Tolerance & VIF & \\
\hline $\mathrm{X}_{1}$ & 0,998 & 1,347 & Tidak Terdapat multikolinieritas \\
\hline $\mathrm{X}_{2}$ & 0,988 & 1,055 & Tidak Terdapat multikolinieritas \\
\hline $\mathrm{X}_{3}$ & 0,995 & 1,218 & Tidak Terdapat multikolinieritas
\end{tabular}

Hasil perhitungan nilai tolerance pada tabel diatas menunjukkan nilai yang mendekati angka 1 dan nilai variance inflation factor (VIF) diatas menunjukkan tidak ada satu variabel bebas yang memiliki nilai VIF tidak lebih dari 5. Jadi dapat disimpulkan asumsi tidak adanya gejala multikolinearitas antar variabel bebas dalam model regresi.

b. Uji Heteroskedastisitas

Uji heteroskedastisitas bertujuan untuk menguji apakah dalam model regresi terjadi ketidaksamaan varian (ragam) dari residual atau pengamatan lain. Pemeriksaan terhadap gejala heteroskedastisitas menurut Pratisto $(2004,155)$ adalah dengan melihat pola diagram pencar. Nilai dari diagram pencar yang residual dapat dilihat dari selisih antara nilai Y prediksi dengan Y observasi. (1) Jika diagram pencar yang membentuk pola tertentu yang teratur, maka regresi mengalami gangguan heteroskedastisitas. (2) Jika diagram pencar tidak membentuk pola atau acak, maka regresi tidak mengalami gangguan heteroskedastisitas. 


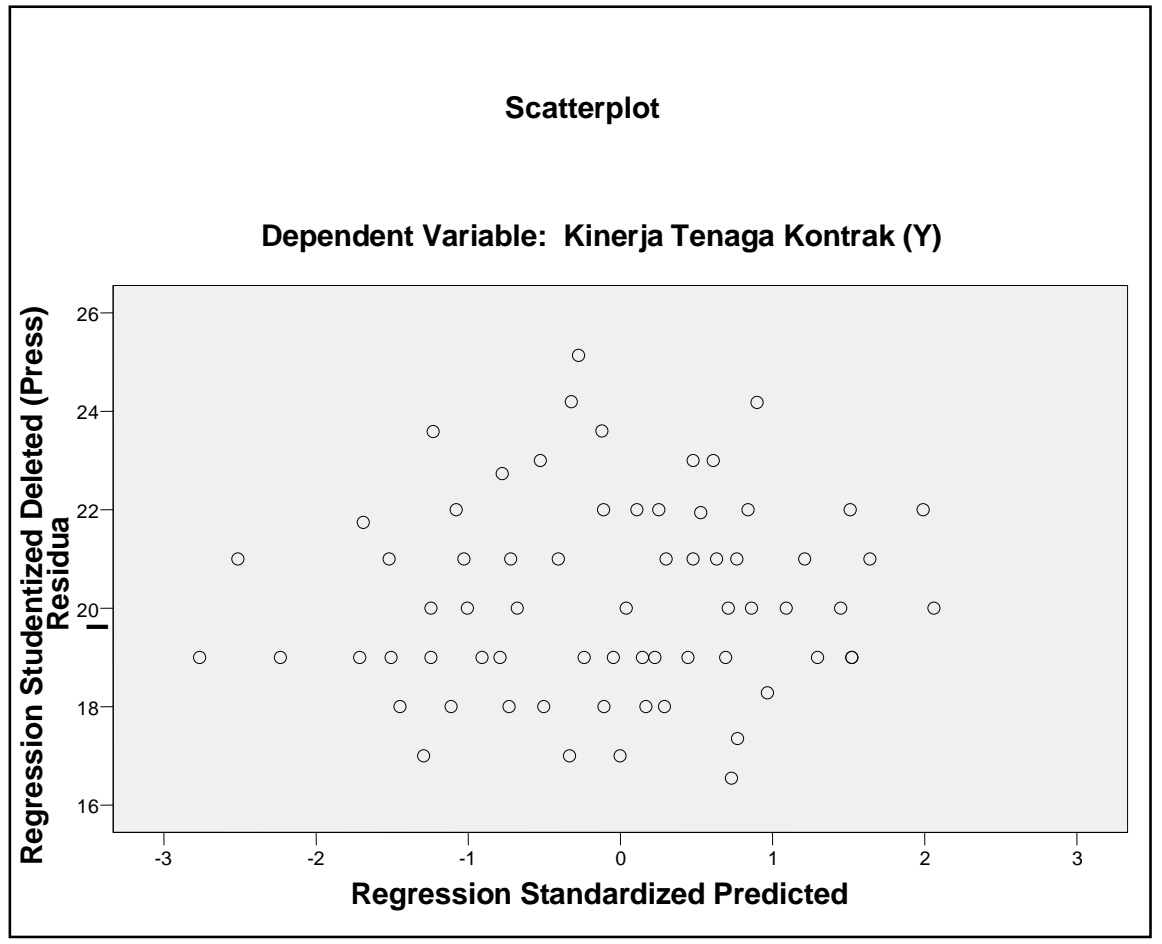

Gambar 1. Diagram Pencar Hasil Heteroskedastisitas

Dalam diagnose heteroskedastisitas di penelitian ini menghasilkan grafik scatterplot menghasilkan penyebaran dalam bentuk pola atau acak, maka hal ini dapat disimpulkan bahwa regresi layak dipergunakan.

c. Uji Normalitas (kenormalan)

Uji normalitas dilakukan untuk mengetahui apakah variabel terikat dan variabel bebas dalam sebuah model regresi mempunyai distribusi normal atau tidak. Asumsi ini sangat diperlukan pada pengujian hipotesis, baik menggunakan uji t pada uji koefesien regresi secara parsial ataupun uji $\mathrm{F}$ pada uji koefesien secara serempak melalui ANOVA regresi.

Normal P-P Plot of Regression Standardized Residual

Dependent Variable: Kinerja Tenaga Kontrak (Y)

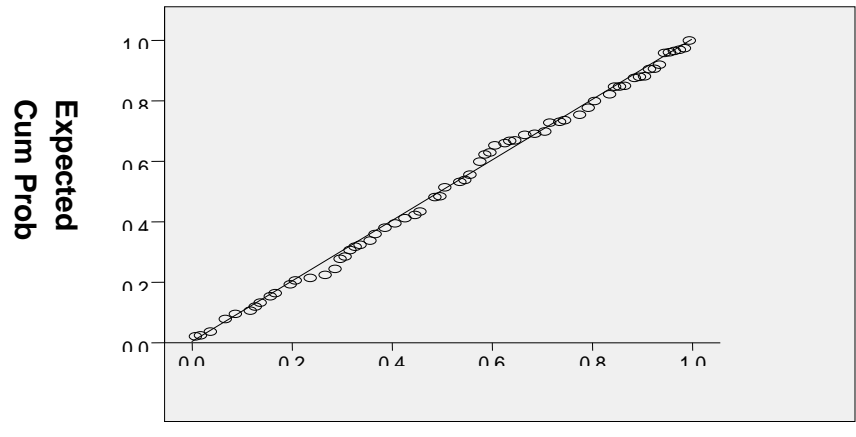

Observed Cum Prob

Gambar 2. Grafik Plot of Regression 
Terlihat titik penyebaran disekitar garis diagonal / menunjukkan pola garis lurus mendekati sudut $45^{\circ}$, maka didapat bahwa semua data berdistribusi normal, sehingga asumsi normalitas terpenuhi.

4. Analisis Regresi Berganda

Untuk menjawab hipotesis, maka perlu diajukan analisis model regresi linier berganda menggunakan alat bantu analisis berupa program SPSS 17 for wndows. Untuk itu adapun hasil uji parsial diketahui dengan melihat data pada tabel 7.

Tabel 7. Coefficients(a)

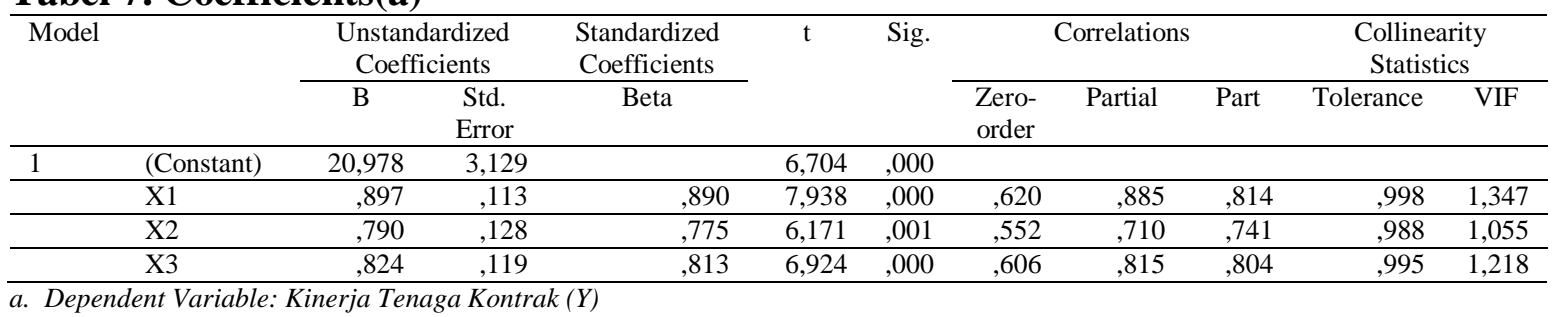

Selanjutnya dapat dibuat persamaan regresinya. Secara matematis model fungsi linear berganda dapat dinyatakan sebagai berikut:

$Y=20,978+0,897 X_{1}+0,790 X_{2}+0,824 X_{3}+e$

a = nilai constanta sebesar 20,978 menunjukkan angka ini berupa angka konstan yang mempunyai arti besarnya kinerja tenaga kontrak saat nilai profesionalisme kerja, penghargaan dan pengawasan kerja sama dengan 0 . hal ini menunjukkan bahwa variabel bebas mempunyai pengaruh signifikan terhadap variabel terikat (kinerja tenaga kontrak).

$\mathrm{b}_{1}=$ mempunyai nilai 0,897 hal ini adalah menunjukkan elastisitas antara indikator profesionalisme kerja terhadap kinerja tenaga kontrak. Angka koefisien regresi pertama ini mempunyai arti bahwa setiap penambahan profesionalisme kerja ke titik kinerja tenaga kontrak, maka tingkat kinerja tenaga kontrak akan naik sebesar 0,897.

$\mathrm{b}_{2}=$ mempunyai nilai 0,790 hal ini adalah menunjukkan elastisitas antara indikator penghargaan terhadap kinerja tenaga kontrak. Angka koefisien regresi kedua ini mempunyai arti bahwa setiap penambahan penghargaan ke titik kinerja tenaga kontrak, maka kinerja tenaga kontrak akan naik sebesar 0,790 .

$\mathrm{b}_{3}=$ mempunyai nilai 0,824 hal ini adalah menunjukkan elastisitas antara indikator pengawasan kerja terhadap kinerja tenaga kontrak. Angka koefisien regresi ketiga ini mempunyai arti bahwa setiap penambahan pengawasan kerja ke titik kinerja tenaga kontrak, maka tingkat kinerja tenaga kontrak akan naik sebesar 0,824.

5. Pengujian Hipotesis

a. Hipotesis secara simultan (hipotesis pertama)

Profesionalisme kerja, penghargaan dan pengawasan kerja secara simultan berpengaruh signifikan terhadap kinerja tenaga kerja kontrak Kebersihan Bidang Pertamanan dan Kebersihan di Dinas Pekerjaan Umum, Penataan Ruang, Perumahan dan Kawasan Permukiman Kabupaten Kapuas.

Untuk menguji hipotesis secara simultan digunakan formulasi fhitung > f tabel, berdasarkan hal tersebut, kemudian harus diketahui terlebih dahulu menilai fhitung, untuk mengetahui nilai f hitung maka perlu ditampilkan data tabel model summary, berikut ini: 
Tabel 8. Model Summary(b)

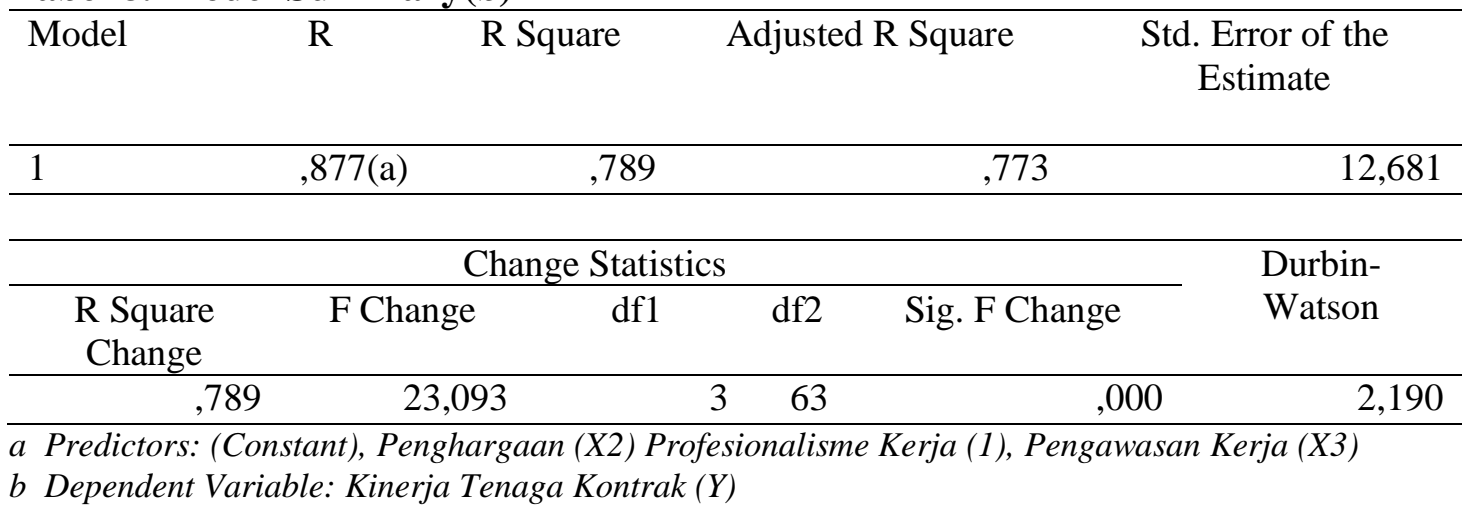

Hasil regresi pada tabel model summary memperlihatkan bahwa F Change (fhitung) sebesar 23,093. Kemudian untuk menentukan nilai ftable dengan tingkat signifikan 5\%. Sedangkan untuk menghitung uji $\mathrm{F}$ digunakan program SPSS, maka penentuan nilai fhitung dengan cara menentukan Derajat bebas bagi pembilang (numerator) adalah (k-1) sehingga didapat $(4-1)=3$, sedangkan derajat kebebasan bagi pembagi (denumerator) adalah (n-k) sehingga didapat $(66-4)=62$. Dengan demikian didapat ftabel dengan numerator $=3$ dan denumurator 62, maka dapat diketahui nilai ftabel sebesar 2,753. Berdasarkan hal tersebut diperoleh fhitung $(23,093)>$ ftabel $(2,753)$ yang berarti variabel bebas yang terdiri dari seperti profesionalisme kerja (X1), penghargaan (X2), dan pengawasan kerja (X3) berpengaruh secara bersama-sama terhadap variabel terikat (kinerja tenaga kontrak (Y)) berdasarkan data tersebut, maka hipotesis pertama (H1) diterima.

Untuk regresi dengan lebih dari dua variabel bebas digunakan $R$ Square sebagai keofesien diterminan dari data tabel 5.15 terlihat $R$ Square sebesar 0,789 disini berarti $78,9 \%$ variasi kinerja tenaga kontrak (Y) bisa dijelaskan oleh variabel seperti profesionalisme kerja (X1), penghargaan (X2), dan pengawasan kerja (X3), sedangkan sisanya dari $(100 \%-78,9 \%)=21,1 \%$ dijelaskan oleh variabel lain yang tidak dianalisis pada penelitian ini seperti faktor pimpinan, faktor lingkungan kerja dan lain-lain.

b. Hipotesis secara parsial (hipotesis kedua)

Profesionalisme kerja, penghargaan dan pengawasan kerja secara parsial berpengaruh signifikan terhadap kinerja tenaga kerja kontrak Kebersihan Bidang Pertamanan dan Kebersihan di Dinas Pekerjaan Umum, Penataan Ruang, Perumahan dan Kawasan Permukiman Kabupaten Kapuas.

Tahapan berikut yaitu pengujian hipotesis secara parsial atau secara sendiri-sendiri untuk menguji hipotesis secara parsial dapat dilakukan dengan membandingkan nilai thitung dengan ttable pada taraf nyata 5\%. Jika thitung > ttable maka pengaruhnya signifikan. Untuk mendapatkan ttabel digunakan tabel distribusi $t$ untuk tingkat signifikasi 5\% dengan Degrees of Freedom (df) = n-k maka didapat df adalah (66-4)= 62 dengan demikian ttabel adalah sebesar 1,670. Berdasarkan data pada tabel 5.14 dapat diketahui nilai thitung masing-masing.

Tabel 9. Data tabel thitung

\begin{tabular}{lc}
\hline \multicolumn{1}{c}{ Nama variabel } & Nilai thitung \\
\hline Profesionalisme kerja (X1) & 7,938 \\
\hline Penghargaan (X2) & 6,171 \\
\hline Pengawasan Kerja (X3) & 6,924 \\
\hline
\end{tabular}


Melihat dari data tersebut, maka dapat dianalisis hipotesis kedua secara parsial sebagai berikut:

1) Profesionalisme kerja terhadap kinerja tenaga kontrak

Melihat dari perbandingan antara thitung untuk variabel Profesionalisme kerja (X1) sebesar 7,938 dan ttabel 1,670 dan tingkat signifikansi $\mathrm{p}=0,000<0,05$. Tingkat kepercayaan yang diambil dalam penelitian ini sebesar $95 \%$ dengan tingkat kesalahan $(\alpha)$ sebesar $5 \%$, ini berarti terdapat pengaruh signifikan antara variabel profesionalisme kerja (X1) dengan variabel terikat yaitu kinerja tenaga kontrak (Y). Besarnya konstribusi (sumbangan) variabel profesionalisme kerja (X1) terhadap kinerja tenaga kontrak (Y) dapat diketahui dari Standardized Coefficients Beta 0,890 (lihat tabel 5.14) yang berarti profesionalisme kerja ini memberikan konstribusi dalam mempengaruhi kinerja tenaga kontrak terhadap sebesar $89 \%$.

2) Penghargaan terhadap kinerja tenaga kontrak

Perbandingan antara thitung untuk variabel penghargaan (X2) sebesar 6,171 dan ttabel 1,670 dan tingkat signifikansi $\mathrm{p}=0,001<0,05$. Tingkat kepercayaan yang diambil dalam penelitian ini sebesar 95\% dengan tingkat kesalahan $(\alpha)$ sebesar 5\%, ini berarti terdapat pengaruh signifikan antara variabel penghargaan (X2) dengan variabel terikat yaitu kinerja tenaga kontrak $(\mathrm{Y})$. Besarnya konstribusi (sumbangan) variabel penghargaan (X2) terhadap kinerja tenaga kontrak (Y) dapat diketahui dari Standardized Coefficients Beta 0,775 (lihat tabel 5.14) yang berarti penghargaan ini memberikan konstribusi dalam mempengaruhi kinerja tenaga kontrak terhadap sebesar $77,5 \%$.

3) Pengawasan kerja terhadap kinerja tenaga kontrak

Untuk variabel pengawasan kerja (X3) sebesar 6,924 dan ttabel 1,670 dan tingkat signifikansi $\mathrm{p}=0,000<0,05$. Tingkat kepercayaan yang diambil dalam penelitian ini sebesar 95\% dengan tingkat kesalahan $(\alpha)$ sebesar 5\%, ini berarti terdapat pengaruh signifikan antara variabel pengawasan kerja (X3) dengan variabel terikat yaitu kinerja tenaga kontrak (Y). Besarnya konstribusi (sumbangan) variabel pengawasan kerja (X3) terhadap kinerja tenaga kontrak (Y) dapat diketahui dari Standardized Coefficients Beta 0,813 (lihat tabel 5.14) yang berarti pengawasan kerja ini memberikan konstribusi dalam mempengaruhi kinerja tenaga kontrak terhadap sebesar $81,3 \%$.

Berdasarkan hasil pengujian hipotesis ini, maka dapat disimpulkan bahwa variabel bebas secara parsial berpengaruh signifikan terhadap variabel terikat, maka hipotesis kedua diterima.

c. Uji Hipotesis Dominan (hipotesis ketiga)

Profesionalisme kerja berpengaruh dominan terhadap kinerja tenaga kerja kontrak Kebersihan Bidang Pertamanan dan Kebersihan di Dinas Pekerjaan Umum, Penataan Ruang, Perumahan dan Kawasan Permukiman Kabupaten Kapuas.

Hipotesis ketiga dalam penelitian ini menyatakan variabel profesionalisme kerja (X1) yang berpengaruh dominan terhadap kinerja tenaga kontrak (Y) terbukti benar, hal ini dikarenakan variabel profesionalisme kerja (X1) memiliki nilai Standardized Coefficients Beta 0,890 (lihat tabel 5.14) nilai ini lebih besar bila dibanding dengan nilai variabel lainnya berdasarkan itulah, maka hipotesis ketiga diterima. 
Profesionalisme kerja, penghargaan dan pengawasan kerja secara simultan berpengaruh signifikan terhadap kinerja tenaga kerja kontrak Kebersihan Bidang Pertamanan dan Kebersihan di Dinas Pekerjaan Umum, Penataan Ruang, Perumahan dan Kawasan Permukiman Kabupaten Kapuas. Pengujian pada hipotesis pertama yaitu profesionalisme kerja, penghargaan dan pengawasan kerja secara simultan berpengaruh signifikan terhadap kinerja tenaga kerja kontrak Kebersihan Bidang Pertamanan dan Kebersihan di Dinas Pekerjaan Umum, Penataan Ruang, Perumahan dan Kawasan Permukiman Kabupaten Kapuas. Hasil penelitian ini sejalan dengan penelitian yang dilakukan oleh Sutarman (2011) yang juga menyatakan pengawasan internal, profesionalisme pegawai dan pemberian penghargaan terhadap kinerja pegawai.

Berdasarkan hal tersebut, hendaknya Dinas Pekerjaan Umum, Penataan Ruang, Perumahan dan Kawasan Permukiman Kabupaten Kapuas dapat mengelola profesionalisme kerja pegawai dengan memberikan peningkatan kemampuan dan kompetensi kepada tenaga kontrak, memberikan penghargaan kepada pegawai yang berprestasi dan menerapkan pengawasan kerja yang lebih baik lagi kepada tenaga kontrak. Untuk menunjang terhadap pencapaian peningkatan kinerja tenaga kontrak tersebut, hendaknya ketiga variabel tersebut dapat dijalankan secara bersama-sama dan pihak Dinas Pekerjaan Umum, Penataan Ruang, Perumahan dan Kawasan Permukiman Kabupaten Kapuas harus mempunyai komitmen yang kuat dalam menjalankan ketiga kebijakan tersebut agar dapat berjalan dengan baik, sehingga harapan untuk mencapai peningkatan kinerja tenaga kontrak dapat dicapai sesuai dengan harapan.

Pengujian pada hipotesis kedua diketahui bahwa variabel profesionalisme kerja, penghargaan dan pengawasan kerja secara parsial berpengaruh signifikan terhadap kinerja tenaga kerja kontrak Kebersihan Bidang Pertamanan dan Kebersihan di Dinas Pekerjaan Umum, Penataan Ruang, Perumahan dan Kawasan Permukiman Kabupaten Kapuas. Penelitian ini sejalan juga dengan penelitian yang dilakukan oleh Fajar Hermawan (2010), yang menyatakan profesionalisme kerja dan pengawasan kerja terhadap kinerja pegawai. Berdasarkan hasil penelitian itulah, maka hendaknya Dinas Pekerjaan Umum, Penataan Ruang, Perumahan dan Kawasan Permukiman Kabupaten Kapuas dapat memperhatikan ketiga variabel seperti profesionalisme kerja, penghargaan dan pengawasan kerja kearah yang lebih baik lagi adapun upaya yang dapat dilakukan untuk meningkatkan kinerja tenaga kontrak tersebut, yaitu:

1. Meningkatkan profesionalisme kerja

a. Meningkatkan performance tenaga kerja dengan cara memberikan pelatihan dan selalu mengevaluasi terhadap pelaksanaan kerja, dan penampilan kerja.

b. Menciptakan kepatuhan pelaksanaan tugas dan kinerja pegawai dengan menanamkan komitmen dalam melakukan pengelolaan pelaksanaan misi kerja agar sesuai dengan tujuan.

c. Meningkatkan loyalitas aparatur agar terbentuk kesetiaan terhadap institusi dalam bekerja.

d. Meningkatkan kemampuan tenaga kontrak dengan memberikan diklat dan membekali mereka dengan berbagai keterampilan yang sesuai dengan bidang pekerjaan mereka.

2. Memberikan penghargaan

a. Pihak instansi dapat memberikan penghargaan dalam bentuk materiil insentif, yaitu alat motivasi yang diberikan dapat berupa uang dan atau barang yang mempunyai nilai pasar, yang dapat memberikan kebutuhan ekonomis, seperti : Kendaraan, rumah, dan lain-lain.

b. Pihak instansi dapat memberikan penghargaan dalam bentuk non materiil insentif, yaitu alat penghargaan yang diberikan berupa barang /benda yang tidak ternilai, yaitu hanya 
memberikan kepuasan/kebanggaan rohani saja, seperti medali, piagam, bintang jasa, dan lain-lain

c. Pihak instansi dapat memberikan penghargaan dalam bentuk kombinasi materiil dan nonmateriil insentif, yaitu alat motivasi yang diberikan untuk berupa materiil (uang dan barang) dan non materiil (medali dan piagam) yaitu pemenuhan ekonomis dan kepuasan.

3. Menerapkan pengawasan

a. Menerapkan pengawasan dari dalam (internal control) pengawasan yang dilakukan oleh aparat atau petugas pengawas yang dibentuk dalam organisasi itu sendiri.

b. Menerapkan pengawasan dari luar (external control) pengawasan yang dari luar berarti pengawasan yang dilakukan oleh aparat pengawas diluar organisasi itu atau bertindak atas nama pimpinan organisasi karena diminta.

c. Menerapkan pengawasan preventif adalah pengawasan dilakukan sebelum rencana dilaksanakan.

d. Menerapkan pengawasan represif adalah pengawasan dilakukan setelah pelaksanaan pekerjaan.

Diketahui bahwa dalam penelitian ini dari ketiga variabel bebas seperti profesionalisme kerja, penghargaan dan pengawasan yang berpengaruh dominan terhadap kinerja tenaga kontrak pada Dinas Pekerjaan Umum, Penataan Ruang, Perumahan dan Kawasan Permukiman Kabupaten Kapuas adalah profesionalisme kerja untuk itulah guna meningkatkan kinerja tenaga kontrak tersebut pihak Dinas Pekerjaan Umum, Penataan Ruang, Perumahan dan Kawasan Permukiman Kabupaten Kapuas perlu memfokuskan pengembangan bagi profesionalisme kerja tenaga kontrak dengan memberikan peningkatan kemampuan/kompetensi bagi tenaga kontrak dengan memberikan pelatihan atau pun memberikan peluang untuk mengikuti program belajar agar pengetahuan dan keterampilan tenaga kontrak dapat lebih meningkat dan dapat meningkatkan kinerja.

\section{Kesimpulan}

Berdasarkan pada serangkaian temuan pada penelitian ini, maka dapat disusun beberapa kesimpulan sebagai berikut:

1. Hasil penelitian terhadap hipotesis pertama diketahui bahwa variabel profesionalisme kerja, variabel penghargaan dan variabel pengawasan kerja secara simultan berpengaruh signifikan terhadap variabel kinerja tenaga kerja kontrak Kebersihan Bidang Pertamanan dan Kebersihan di Dinas Pekerjaan Umum, Penataan Ruang, Perumahan dan Kawasan Permukiman Kabupaten Kapuas.

2. Hasil penelitian pada hipotesis kedua diketahui pula bahwa variabel profesionalisme kerja, variabel penghargaan dan variabel pengawasan kerja secara parsial berpengaruh signifikan terhadap variabel kinerja tenaga kerja kontrak Kebersihan Bidang Pertamanan dan Kebersihan di Dinas Pekerjaan Umum, Penataan Ruang, Perumahan dan Kawasan Permukiman Kabupaten Kapuas.

3. Hasil penelitian pada hipotesis ketiga diketahui bahwa variabel profesionalisme kerja berpengaruh dominan terhadap kinerja tenaga kerja kontrak Kebersihan Bidang Pertamanan dan Kebersihan di Dinas Pekerjaan Umum, Penataan Ruang, Perumahan dan Kawasan Permukiman Kabupaten Kapuas. 
Berdasarkan pada serangkaian kesimpulan yang telah dikemukakan, maka dapat dibuat beberapa saran sebagai berikut:

1. Hendaknya Dinas Pekerjaan Umum, Penataan Ruang, Perumahan dan Kawasan Permukiman Kabupaten Kapuas dapat mengelola profesionalisme kerja pegawai dengan memberikan peningkatan kemampuan dan kompetensi kepada tenaga kontrak, memberikan penghargaan kepada pegawai yang berprestasi dan menerapkan pengawasan kerja yang lebih baik lagi kepada tenaga kontrak.

2. Hendaknya Dinas Pekerjaan Umum, Penataan Ruang, Perumahan dan Kawasan Permukiman Kabupaten Kapuas dapat memperhatikan ketiga variabel tersebut, dengan cara meningkatkan profesionalisme kerja melalui meningkatkan performance pegawai, menciptakan kepatuhan, meningkatkan loyalitas dan meningkatkan kemampuan tenaga kontrak dengan memberikan diklat dan membekali mereka dengan berbagai keterampilan yang sesuai dengan bidang pekerjaan mereka dan memberikan penghargaan dalam bentul materiil insentif maupun materiil insentif serta materiil dan nonmateriil insentif. Menerapkan pengawasan dari dalam, dari luar, preventif dan pengawasan represif.

3. Dinas Pekerjaan Umum, Penataan Ruang, Perumahan dan Kawasan Permukiman Kabupaten Kapuas perlu memfokuskan pengembangan bagi profesionalisme kerja tenaga kontrak dengan memberikan peningkatan kemampuan/kompetensi bagi tenaga kontrak dengan memberikan pelatihan atau pun memberikan peluang untuk mengikuti program belajar agar pengetahuan dan keterampilan tenaga kontrak dapat lebih meningkat dan dapat meningkatkan kinerja.

4. Untuk meningkatkan profesionalisme pegawai dalam rangka meningkatkan kinerja pegawai, maka para egawai kontrak harus mempunyai kepatuhan terhadap pelaksanaan tugas dalam bekerja mempunyai kesetiaan terhadap konstitusi, hukum, pimpinan, bawahan dan rekan sekerja serta peningkatan kematangan dari segi pengetahuan, keterampilan dalam bidang pekerjaanlah kunci yang peru ditingkatkan tenaga kontrak.

\section{DAFTAR PUSTAKA}

Ancok. Pahpahan, 2008, Manajemen Organisasi dan Perilaku Keorganisasian, Bumi Aksara, Jakarta

Alfonso 2009, Manajemen, Rineka Cipta, Jakarta

As'ad. Muchtar, 2001, Profesionalisme Pegawai, Liberty, Jakarta

Abdurrachman. Arifin, 2008, Filosofi dan Etika Manajemen Umum, Ichtiar Baru, Jakarta

Atinosudido, 2002, Ilmu Administrasi dan Manajemen Perusahaan, Liberty, Yogyakarta

Arikunto, 1992, Prosedur Penelitian Suatu Pendekatan dan Praktek, Rineka Cipta, Jakarta

Baldauf, Peter F. Drucker, 2001, An Experiential Approach to Organization Development, Seventh Edition (Delhi : Pearson Education Inc) p.219

Danim dan Suparno, 2009, Manajemen SDM, Cakrawala, Yogyakarta

Dessler, Gary, 2000. Manajemen Sumber Daya Manusia. Jilid III. Prenhallindo. Jakarta

Dwi Sulastri, 2009 Pengaruh Kemampuan Kerja, Reward dan Motivasi Terhadap Kinerja pegawai pada Kantor Pertanahan Kota Banjarmasin, Unlam Banjarmasin

Fajar Hermawan, 2010, Pengaruh Loyalitas, Profesionalisme Kerja dan Pengawasan Kerja Terhadap Kinerja Karyawan Pada Perusahaan Daerah Air Minum Kabupaten Balangan, STIEPAN, Banajrmasin

Ferdinand, 2006, Analisis Penelitian dengan Aplikasi Amos dan SPSS, Rajawali Press, Jakarta

Guritno dan Waridin, 2005, Manajemen SDM, BPFE, Yogyakarta

Gomes Faustino.C, 2005, Manajemen Sumber Daya Manusia, Andi, Yogyakarta

Ghozali, Imam, 2006. Uji Asumsi Klasik Dengan Program SPSS, PT. Elexmetindo, Undip, Semarang. 
Hasibuan. Malayu, 2007, Manajemen SDM dan Kepersonalian, Edisi Revisi, BPFE, Yogyakarta

Handoko.T.Hani, 2004, Manajemen Personalia dan Sumber Daya Manusia, Edisi Revisi, Penerbit BPFE, Yogyakarta 2010, Manajemen Personalia dan Sumber Daya Manusia, Edisi Baru,

Penerbit BPFE, Yogyakarta

Handayaningrat. S, 2006, Pengantar Studi Administrasi dan Manajemen. PT. Gunung Agung, Jakarta

Kadarman, 2001, Control Internal Organisasi, Balai Pustaka, Jakarta

Kartasasmita, 2007, Budaya Profesionalisme, Alumni, Jakarta

Mahmud,1998, Keorganisasian dan SDM, Pustaka, Jakarta

Manullang, 2008, Manajemen SDM dan Keorganisasian, Ghalia Indonesia, Jakarta

Mas'ud, 2004, Metode Penelitian Ilmiah, Alfabeta, Jakarta

Maman Ukas, 2004, Manajemen Perusahaan, Liberty, Jakarta

Mulyanto, 2012, Pengaruh Pengawasan Kerja Dan Profesonalisme Kerja Terhadap Kinerja Pegawai, FE Unlam, Banjarmasin

Mangkunegara. A.A. Anwar Prabu. 2001. Manajemen Sumber Daya Manusia Perusahaan. Penerbit PT. Remaja Rosdakarya. Bandung

Marihot. Effendi, 2012, Manajemen Prestasi Kerja. Edisi 1 Jakarta: Rajawali.

Nitisemito, Alex, 1996, Manajemen Personalia (SDM), Ghalia Indonesia, Jakarta , 2006, Manajemen Personalia (SDM), Edisi Revisi, Ghalia Indonesia, Jakarta

Nurakhman, 2012 Pengaruh Profesionalisme Kerja Dan Pengawasan Kerja Terhadap Kinerja Pegawai Dishub Kota Banjarmasin, FE Unlam, Banjarmasin

Priyatno, 2008, Cara Mudah Mengatasi Statistik dan Rancangan Percobaan dengan SPSS 12, PT Elex Media Komputindo Kelompok Gramedia, Jakarta

PP No. 99 tahun 2000, tentang kenaikan pangkat PNS, jo PP No.12 tahun 2002, Jakarta

PP No.100 tahun 2000 tentang pengangkatan PNS dalam jabatan struktural, jo PP No.13 tahun 2002. dan Kepka BKN No.13 Tahun 200, Jakarta

PP No. 16 tahun 1994, tentang jabatan fungsional PNS, jo No. 40 tahun 2010, Jakarta

PP No. 25 tahun 1994, tentang Tanda Kehormatan Satyalencana Karya Satya dan Kepka BAKN, No. 2 tahun 1995, Jakarta

Pratisto, 2004, Riset Penelitian, Rajawali Press, Jakarta

Royen, 2007, Manajemen Produktivitas, Buana Press, Bandung

Rivai, Veithzal, 2009, Manajemen Sumber Daya Manusia Untuk Perusahaan, Edisi Kedua, PT. RajaGrafindo Persada Jakarta

Prawirisentono, 1999, Evaluasi Pelatihan Dalam Rangka Peningkatan Produktivitas., Mandar Maju, Bandung

Sujamto, 2000, Azaz-azaz Pengawasan, Ghalia Indonesia, Jakarta

Suradinata, 2005, Perilaku Organisasi, UGM, Yogyakarta

Soemanto, 1998, Pengantar Ilmu Manajemen, Salemba Humanika, Jakarta

Soerwarno, 1998, Pengawasan dan Pembinaan Pegawai, Rajawali Press, Jakarta

Sumarsono, 2014, Metodologi dan Komputer Statistik, Multindo, Jakarta

Simamora, Henry. 2010. Manajemen Sumber Daya Manusia. Penerbit STIEYKPN, Yogyakarta

Sosrohamidjojo. S, 2002, Pengelolaan dan Pengawasan Personil, LAN, Jakarta

Sardiman, 2002, Manajemen Sumber Daya Manusia, Rajawali Press, Jakarta

Sugiyono, 2011, Stasistik Untuk Penelitian, CV. Alfabeta, Bandung

Swansburg, Greenberg, 1999, Organizational Management. Journal of Economic \& Management, Vol15: 99-106

Suparno, 2002, Metode Penelitian, Rineka Cipta, Jakarta 
Sutarman, 2011, Pengaruh Pengawasan Internal, Profesionalisme Pegawai dan Pemberian Penghargaan Terhadap Kinerja Pegawai Pada Kantor Koperasi dan UKM Kabupaten Banjar, STIEPAN, Banjarmasin

Siagian. F.S, 2001, Manajemen SDM dan Personalia, Ghalia Indonesia, Jakarta , 2003, Manajemen SDM dan Personalia, Edisi Revisi Jilid I, Ghalia Indonesia, Jakarta Jakarta , 2007, Manajemen SDM dan Personalia, Edisi, Revisi, Jilid II, Ghalia Indonesia,

Sujamto, 2010, Pengantar Ilmu Manajemen, Rineka Cipta, Jakarta

Schuler , 1997, Organizational climate, job satisfaction and Integrity job anxiety. Psychological Studies, Vol.34, pp.21-27.

Suseno, 2007, Manajemen dan Profesionalisme Kerja, Gramedia, Jakarta

Sumarmo, 2004, Manajemen Organisasi, Rineka Cipta, Jakarta

Sukarna, 1992, Manajemen Kepegawaian, Pustaka, Jakarta

Tjokrowinoto, 2006, Profesionalisme dan Integritas Kerja, Media Pustaka, Jakarta

Umar. Hasan, 2010, Penulisan Karya Ilmiah dan Metode Riset, Rajawali Press, Jakarta

Winardi, 1986, Pengantar Ilmu Manajemen, Nova, Bandung

Wignjosoebroto, 2009, Manajemen Perusahaan, Nova, Bandung

Zuhad, 2006, Pengawasan Melekat Bagi PNS, Media Pustaka, Surabaya 